ella hizo, puesto que serviría de enseñanza práctica al pueblo español en las actuales circunstancias. Pero Cristóbal de Castro no es un erudito. Se ha contentado con hacer profesión de liberalismo y recorrer los diarios y gacetas de la época, para formar un libro repleto de adjetivos, declamatorio e insuficiente desde el punto de vista histórico y biográfico.-F. Ortuzar Via'.

\section{Elisabeth AND Essex, por Lytton Strachey.}

Lo que da el tono y la calidad de Lytton Strachey entre los contemporáneos autores de biografía, es además de un estilo de perfecta elegancia británica, un estilo fluido como una conversación, su manera peculiarísima de enfocar el personaje histórico que no tiene semejanza alguna con el método de Ludwig o de Maurois. Muy escasa es la bibliograffade Lytton Strachey. Apenas cuatro libros que versan sobre los dos períodos más característicos de la historia inglesa, aquellos en que el genio del hombre inglés se presenta al observador con mayor relieve $y$ mayor cualidad diferenciadora. El período de la Reina Isabel con que parece empezar, mejor que con el advenimiento de los Tudores, la historia moderna inglesa: esos cuarenta últimos años del siglo XVI y primeros años del XVII que son los de la formación del poderío marítimo de Inglaterra, los años de Drake y de Sir Walter Raleigh, que corresponden en el terreno de la cultura al drama de Shakespeare y al Novum Organum de Bacon. Y esos cincuenta y tres últimos años del siglo XIX en que la vieja Inglaterra se siente segura $y$ prolítica bajo la sombra augusta de la abuela Victoria. Isabel y Victoria. dos mujeres fuertes como la raza, que amamantan la historia inglesa.

Es así Lytton Strachey un biógrafo de reinas. Pero sabe defenderse de la exaltación y del patetismo, con un comedimiento a veces frío, en que estriba su perfecta objetividad de biógrafo. Objetividad, hemos dicho. $\mathrm{Si}$ lo comparamos con Ludwig, el gran biografista alemán, exaltado y bíblico como su raza judía, resaltaría claramente la diferencia. En Ludwig el autor parece intervenir a cada momento en la vida de sus personajes, emplea el contraste y el clarobscuro, arrastra una prosa dilatada, sacudida de pronto por exclamaciones. Hay en Ludwig mucho más retórica y subjetivismo. De aquí la preocupación de Ludwig por el retrato. La etopeya es en Ludwig todo un género literario. Sus retratos podrían entresacarse de sus biografías formando piezas aparte. Se ve el procedimiento del escritor que concibe a su personaje con un colorido y una luz especial, y en el momento de retratarlo precipita sobre el papel todos los colores. El retrato de Lytton Strachey tiene otra estructura. No se podrían entresacar sus retratos. Circulan por el cuerpo de la obra como un agua subterránea. Lo mismo que en la vida no se nos presentan de un golpe las cualidades o defectos de un individuo, en los personajes de Strachey siempre hay algo por descubrir y adivinar. ¿A dónde irá este 
personaje? se pregunta el lector. La tragedia de Gordon en Eminents Victorians y la tragedia de Essex en Elisabeth, se va desenvolviendo lentamente: los sucesos suelen desviarla, presentarle esperanzas y líneas curvas, lo mismo que en la vida. Pensamos en el retrato de Francisco $\mathrm{Ba}-$ con en Elisabeth. Ese retrato diluido entre las trescientas páginas de la obra es inolvidable. La inteligencia, la ironía y la flaqueza humanas, le dan un maravilloso color de contraste. Y el autor no se pronuncia en ningun momento. Sencillamente hace vivir a Francisco Bacon. Lo deja en libertad, pero anota sí con escrupulosidad estadística las caídas y contradicciones morales de su personaje. En el comienzo de la obra Bacon es un gentilhombre culto $y$ tronado. Posee una cultura ornamental, un fino don de análisis y una perfecta prosa, tanto latina como inglesa. Lady Bacon, alma puritana que teme al Infierno, no sabe qué hacer con este hijo que vive en pecado mortal y cada día aumenta sus deudas. Anthony Bacon, su hermano, tipo del hombre documentado y formal (funcionaric nato, de esos hombres correctos de que en nuestra época suelen surgir los directores de servicios o los subsecretarios de Ministerios), tiene la debilidad de amar mucho a Francisco, creer en su talento y perdonarle las calaveradas. Por intermedio del recto Anthony Bacon, Francisco conoce al Conde de Essex. Essex es un carácter antípoda: brillante, impetuoso, irreflexivo, buen corazón, todo instinto $y$ aventura. Francisco Bacon adula a Essex. Tiene los recursos de su sutil prosa bilingüe. Bacon ha estudiado la Historia de las naciones y el destino de las monarquías. La preocupación de Essex es buscarle a Bacon, durante muchos años, un puesto a la altura de sus deudas, siempre crecientes. Tiene que luchar contra la testarudez y la desconfianza de la Reina Isabel. Bacon desplaza una gran actividad epistolar. Essex no trepida en disgustarse con la Reina por servir a este solicitante en quien ve un amigo. Los amigos del Conde de Essex. Tenía el Conde un sentido heroico y gallardo de la amistad. Nunca adivina que este Bacon es una vulpeja. Y el destino, el clima de la tragedia, quiere que la Reina Isabel que lo ha desdeñado muchos años, conozca a Bacon y lo utilice en el momento en que empieza el infortunio político del Conde de Essex. Un humanista como Bacon tiene el derecho de ser olvidadizo. Bacon, que posee argumentos jurídicos para todo, será el acusador del Conde de Essex. Ascenderá por fin, con la desgracia de su amigo. Podrá pagar sus deudas atrasadas y contraer otras nuevas. La vida de un filósofo, del autor del Novum Organum, no puede regirse por la moral de los hombres corrientes. Esta la ironía de Lytton Strachey: sus libros son como herbarios de hombres. Su fina prosa acerada, va pegando objetiva y serenamente, como plantas en un herbario, los rasgos y defectos distintivos de la especie hombre. No se pronuncia: tiene el don de escuchar a sus personajes. Respeta su clase social y sus peculiaridades de expresión. Resucita así, sin alarde, todo el espíritu de una época.-M. Picón-Salas. 